\title{
CHRONOFUNCTIONS OF HEILU SOIL DEVELOPED FROM LOESS IN LUOCHUAN, ON THE CHINESE LOESS PLATEAU ${ }^{(1)}$
}

\author{
Gang Liu ${ }^{(2)}$, Wennian $\mathrm{Xu}^{(3)} \&$ Chongfa $\mathrm{Cai}^{\left(4^{*}\right)}$
}

\begin{abstract}
SUMMARY
Soil chronofunctions are an alternative for the quantification of soil-forming processes and underlie the modeling of soil genesis. To establish soil chronofunctions of a Heilu soil profile on Loess in Luochuan, selected soil properties and the ${ }^{14} \mathrm{C}$ ages in the Holocene were studied. Linear, logarithmic, and thirdorder polynomial functions were selected to fit the relationships between soil properties and ages. The results indicated that third-order polynomial function fit best for the relationships between clay $(<0.002 \mathrm{~mm})$, silt $(0.002-0.02 \mathrm{~mm})$, sand (0.02-2 $\mathrm{mm}$ ) and soil ages, and a trend of an Ah horizon ocurrence in the profile. The logarithmic function indicated mainly variations of soil organic carbon and pH with time (soil age). The variation in $\mathrm{CaCO}_{3}$ content, $\mathrm{Mn} / \mathrm{Zr}, \mathrm{Fe} / \mathrm{Zr}, \mathrm{K} / \mathrm{Zr}, \mathrm{Mg} / \mathrm{Zr}$, $\mathrm{Ca} / \mathrm{Zr}, \mathrm{P} / \mathrm{Zr}$, and $\mathrm{Na} / \mathrm{Zr}$ ratios with soil age were best described by three-order polynomial functions, in which the trend line showed migration of $\mathrm{CaCO}_{3}$ and some elements.
\end{abstract}

Index terms: ${ }^{14} \mathrm{C}$ age, soil properties, element migration, soil development.

(1) This research was jointly supported by the China Postdoctoral Science Foundation (Grant No. 20110491162), Fundation of Hubei Provincial Department of Education (Grant No. Q20111207, XD20100595), Open Research Fund Program of the State Key Laboratory of Soil Erosion and Dryland Farming on the Loess Plateau (Grant No. 10501-266), and Foundation of China Three Gorges University (Grant No. KJ2009B033, KJ2009A002). Received for publication in November 23, 2010 and approved in May 17, 2011.

(2) Associate professor, Key Lab of Subtropical Agriculture \& Environment, Ministry of Agriculture, Huazhong Agricultural University, Wuhan 430070, China, and State Key Laboratory of Soil Erosion and Dryland Farming on the Loess Plateau, Institute of Soil and Water Conservation, CAS and MWR, Yangling 712100, China. E-mail: gliu@foxmail.com

(3) Full Professor, Key Laboratory of Geological Hazards on Three Gorges Reservoir Area, Ministry of Education, China Three Gorges University, Yichang 443002, China. E-mail: wnxu@ctgu.edu.cn

(4) Corresponding author, full professor, Key Lab of Subtropical Agriculture \& Environment, Ministry of Agriculture, Huazhong Agricultural University, Wuhan 430070, China. E-mail: cfcai@mail.hzau.edu.cn 


\title{
RESUMO: CRONOFUNÇÕES DO SOLO "HEILU” DESENVOLVIDO DE LOESS EM LUOCHUAN, PLATEAU DE LOESS DA CHINA
}

\begin{abstract}
Cronofunção de solo é uma alternativa para quantificar processos de formação de solo e o fundamento para a modelagem da gênese de solo. Para estabelecer essas cronofunções, propriedades de solos selecionadas e datação com ${ }^{14}$ C no Holoceno, em perfil do solo "Heilu" em um Loess de Luochuan, foram estudadas. Funções linear, logarítmica e polinomial de terceira ordem foram selecionadas para ajustar as relações entre propriedades e idades dos solos. Os polinômios de terceira ordem apresentaram o melhor ajustamento para as relações entre argila $(<0,002 \mathrm{~mm})$, silte $(0,002-0,02 \mathrm{~mm})$, areia $(0,02-2 \mathrm{~mm})$ e idades dos solos e uma tendência para a presença de horizonte Ah no perfil. A função logarítmica indicou preferencialmente variações no conteúdo de C orgânico e pH com o tempo (idade do solo). A variação no conteúdo de $\mathrm{CaCO}_{3}$ e nas razões $\mathrm{Mn} / \mathrm{Zr}, \mathrm{Fe} / \mathrm{Zr}, \mathrm{K} / \mathrm{Zr}, \mathrm{Mg} / \mathrm{Zr}, \mathrm{Ca} / \mathrm{Zr}, \mathrm{P} / \mathrm{Zr}$ e $\mathrm{Na} /$ $\mathrm{Zr}$ com a idade do solo foi mais bem descrita pelas funções polinomiais de terceira ordem, nas quais, como tendência, observou-se migração de $\mathrm{CaCO}_{3}$ e de alguns elementos.
\end{abstract}

Termos de indexação: datação de ${ }^{14} \mathrm{C}$, migração de elementos, desenvolvimento de solo.

\section{INTRODUCTION}

Since soil genesis can hardly be observed directly over decades and centuries, the research of soil chronosequences is the most suitable way to obtain quantitative knowledge on soil development (Vreeken, 1975; Bockheim, 1980). A soil chronosequence is a quantitative description of how the soil properties in a given area change with time (Vincent, 1994). Soil chronofunctions have been equated with the mathematical expression of chronosequence data, typically utilizing correlations and curve-fitting, or some derived combination. They are useful for studying pedogenesis, relative dating of surfaces and geologic events, and for predicting recovery rates of disturbed soils. Therefore, numerous studies on chronosequences and chronofunction construction were carried out in the last decades (e.g. Bockheim, 1980; Huggett, 1998; Wilcke et al., 2003). Most of the soil chronosequence studies suggest linear, power, exponential or logarithmic changes of soil properties with time (Bockheim, 1980; Birkeland, 1984; Huggett, 1998). However, these functions are not always the best option for chronofunctions. Hyperbolic, polynomial or nonlinear functions might improve not only the fit of the chronofunction but also advance our understanding of the pedologic system. The appropriate chronofunction model should be selected for both a good fitting, as well as theoretically matching the expected temporal trend (Schaetzl et al., 1994). After a chronofunction has been obtained from a data set, the y-intercept may also be used to reconstruct the situation at time zero (Schaetzl et al., 1994).

The well preserved Heilu soil could provide important information about the environmental evolution on the Chinese Loess Plateau in the Holocene (Liu, 1965; Tang \& He, 2004). Heilu soils are principal soil components on gently rolling or undulating land surfaces of the Loess Plateau, where past erosion was limited. Several studies on chronosequences of the Heilu soil profile were carried out, but the chronofunctions were seldom descibed (Hu, 1994; Chen et al., 1998; Tang \& He, 2002). The aim of this study was to characterize properties in a wellconstrained and dated Holocene Heilu soil profile, establishing soil chronofunctions to improve the understanding of soil formation and development with time, to provide a theoretical basis for predictions of soil recovery and data for modeling soil genesis (Finke $\&$ Hutson, 2008).

\section{MATERIALS AND METHODS}

\section{Study area}

The Loess Plateau in northwest China covers an area of $530,000 \mathrm{~km}^{2}$, larger than Spain and almost as large as France; the thickness of the loess cover ranges from about 30 to $80 \mathrm{~m}$. The loessial soils are characterized by yellowish colors, absence of bedings, silty texture, looseness, macroporosity and collapsibility when saturated. The Loess Plateau is divided into three zones: sandy loess in the northern part, typical loess in the middle, and clayey loess in the south (Liu, 1965). The soil chronosequence studied

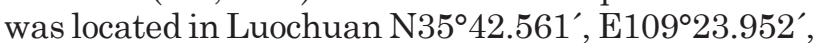
where the landform is a loess tableland, in the center of the Chinese Loess Plateau (Figure 1). The climate of this area is characterized as warm and semi-humid continental monsoonal. Mean annual precipitation in Luochuan is about $622 \mathrm{~mm}$, concentrated in the summer (July to September). In contrast, the climate is cold and dry in winter, with little rainfall. The mean annual temperature is $9.2^{\circ} \mathrm{C}$. The current vegetation in the study area is dominated by grasses and shrubs (Poaceae, Leguminosae, Labiatae, Rhamnaceae, and Compositae). 

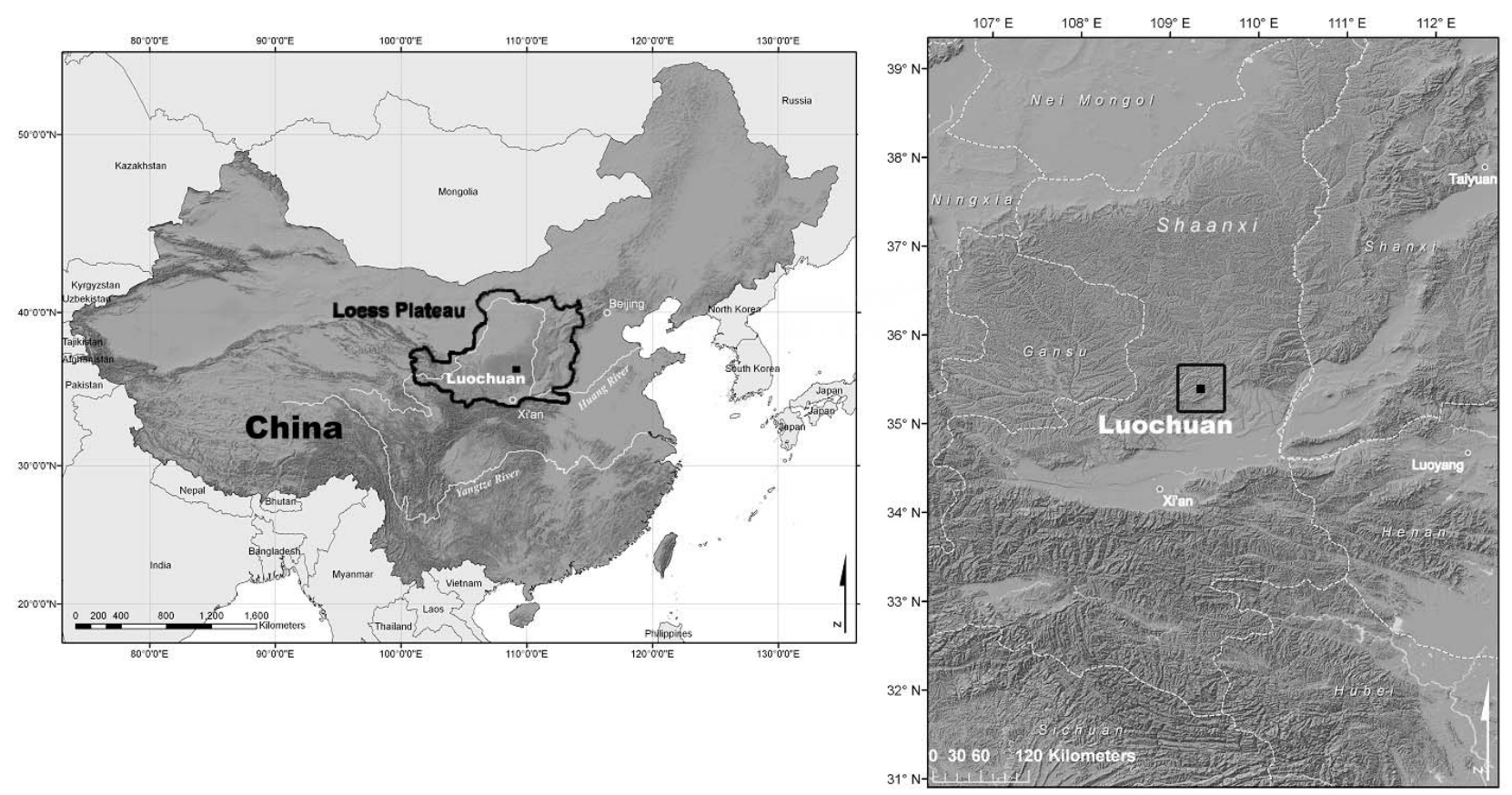

Figure 1. Location of the soil chronosequence within the study area in Luochuan, China.

\section{Field work and laboratory analyses}

The soil layers were sampled from the face wall of a hand-dug pit, approximately $50 \times 200 \mathrm{~cm}$ at the top and about $200 \mathrm{~cm}$ deep. The samples were uniformly obtained the pit walls at $10-\mathrm{cm}$ intervals and the soil morphology routinely described. The interval was occasionally adapted, to avoid sampling across a horizon boundary.

In the laboratory, after air-drying and removing visible roots and stone fragments, samples were passed through a $2 \mathrm{~mm}$ sieve. The amounts of organic carbon and carbonate-carbon were determined by a carbon analyzer with stepped heating of the dried sample in a Leco multiphase carbon analyzer (RC 412), successively measuring both carbon fractions in two replicates. After pretreatment to remove organic matter, particle size analysis was carried out by a laser granulometer. The $\mathrm{pH}$ was determined in deionized water at a soil:water ratio of 1:2.5 (Schlichting et al., 1995). The total elements, including $\mathrm{Mn}, \mathrm{Fe}, \mathrm{K}, \mathrm{Na}$, $\mathrm{Ca}, \mathrm{Mg}$, and $\mathrm{Zr}$ were determined by $\mathrm{X}$ ray fluorescence analysis (XRF) of fused discs. $\mathrm{P}$ was extracted sequentially by the procedure developed by Hedley et al. (1982) and measured by an absorption spectrophotometer.

For all soil samples, humin extraction and radiocarbon dating were carried out at the $\mathrm{AMS}{ }^{14} \mathrm{C}$ laboratory of the Institute of Earth Environment, Chinese Academy of Sciences, China. Many ${ }^{14} \mathrm{C}$ results indicate possible contamination with younger material, modifying results, which can therefore be considered as minimum ages only. Zhou et al. (1990) studied one section in the Loess Plateau (Bei Zhuang
Cun) in great detail, and established a reliable chronology after developing specific sample pretreatment techniques for the site.

\section{Data evaluation}

The results of the laboratory analyses were evaluated by analyzing soil depth functions and chronofunctions. In this study, three kinds of widely used functions (Bockheim 1980; Schaetzl et al., 1994) including linear $(Y=a+b X)$, logarithmic $(Y=a+b \ln$ $X)$, and third-order polynomial equations $(Y=a+b X$ $\left.+c X^{2}+d X^{3}\right)$ were fit to the relationships between soil properties $(Y)$ and soil ages $(X)$. The appropriate chronofunction model was selected by the coefficient of determination $\left(\mathrm{r}^{2}\right)$ and the expected temporal trend was matched theoretically.

\section{RESULTS AND DISCUSSION}

\section{Soil morphology and classification}

Zhu (1983) proposed the name Heilu for a kind of soil that differs clearly from the regional light "Chestnut" and "Kastanozems" soils. Heilu soils have brownish dark grey humus horizons at the surface that are usually 60-100 cm thick. Below the humusrich horizons, the deeper horizon is light gray-brown in color. Predominant textures in the profile are light to medium loam although the humus-rich A horizon contains 8.5-22 \% clay. Illuvial Carbonate precipitates from deeper horizon appear mostly in pseudomycelial and powdery form. Small numbers of carbonate 
microconcretions are also present in depth, both in the soil and the underlying loess material. According to all morphological traits, the sampled pedon was classified as Heilu type soil in this study (Table 1). The ages of the Heilu soil profile ranged from $841 \pm 32$ to $12816 \pm 40$ radiocarbon years BP (Table 2 ).

The most noticeable pedogenic processes in the field are organic carbon accumulation and calcium carbonate leaching in the upper centimeters of the soils, and illuviation further down the profile a few decimeters below. The calcium carbonate accumulations are very intensity in the Holocene soils.

\section{Particle size distribution}

The particle size distribution clearly reflected the predominance of silt $(0.002-0.02 \mathrm{~mm})$ and clay $(<0.002 \mathrm{~mm}$ ) (by International Particle Size Classification System) in the Ah horizon, indicating that clay formation was mainly restricted to the upper layer. A thinning of the upper horizons with increasing age has often been reported in chronosequences (Barrett, 2001).

Logarithmic functions for the different particle classifications were not statistically significant (Table 3).

Table 1. Soil horizon designations

\begin{tabular}{|c|c|c|}
\hline Horizon & Depth & Description \\
\hline & $\mathrm{cm}$ & \\
\hline Ap & $0 \sim 21$ & $\begin{array}{l}\text { Light grayish brown, 10YR7/6 (moist), clay loam, weak medium granular structure, slightly hard (dry), } \\
\text { abundant roots, some small spots of carbonate pseudomycelia, gradual smooth boundary. }\end{array}$ \\
\hline $\mathrm{Ah}$ & $80 \sim 100$ & $\begin{array}{l}\text { Darkish brown, } 7.5 \text { YR3/3 (moist), clay loam, fine subangular blocky structure, hard (dry), abundant roots, } \\
\text { some pseudomycelia in root channels, a few krotowinas filled with C-material, smooth boundary. }\end{array}$ \\
\hline $\mathrm{AB}$ & $80 \sim 100$ & $\begin{array}{l}\text { Color heterogeneity, darkish brown blocks in pale brown soils, clay loam, fine subangular blocks break to } \\
\text { granules, slightly hard (dry), few roots, rich in pseudomycelia, smooth boundary. }\end{array}$ \\
\hline $\mathrm{Bk}$ & $100 \sim 129$ & $\begin{array}{l}\text { Very pale brown, } 7.5 \mathrm{YR} 5 / 3 \text { (moist), clay loam, massive, hard (dry), some very fine pores, few pseudomycelia, } \\
\text { some lime nodules of } 0.5-1 \mathrm{~cm} \text { in diameter, few roots, clear boundary. }\end{array}$ \\
\hline $\mathrm{C}$ & $129 \sim 200$ & Yellowish brown, 10YR8/4 (moist), clay loam, blocks breaking to granules, slightly hardened (dry), few roots. \\
\hline
\end{tabular}

Table 2. Soil ages of each sampling layer

\begin{tabular}{rccccccccccc}
\hline Depth (cm) & $\mathbf{0 - 1 0}$ & $\mathbf{1 0 - 2 0}$ & $\mathbf{2 0 - 3 0}$ & $\mathbf{3 0 - 4 0}$ & $\mathbf{4 0 - 5 0}$ & $\mathbf{5 0 - 6 0}$ & $\mathbf{6 0 - 7 0}$ & $\mathbf{7 0 - 8 0}$ & $\mathbf{8 0 - 9 0}$ & $\mathbf{9 0 - 1 0 0}$ \\
${ }^{14}$ C-year (a) & $841 \pm 32$ & $1714 \pm 21$ & $2275 \pm 26$ & $2970 \pm 21$ & $3171 \pm 24$ & $3686 \pm 30$ & $3999 \pm 23$ & $4443 \pm 31$ & $4901 \pm 25$ & $5651 \pm 26$ \\
& & & & & & & & \\
Depth (cm) & $\mathbf{1 0 0 - 1 1 0}$ & $\mathbf{1 1 0 - 1 2 0}$ & $\mathbf{1 2 0 - 1 3 0}$ & $\mathbf{1 3 0 - 1 4 0}$ & $\mathbf{1 4 0 - 1 5 0}$ & $\mathbf{1 5 0 - 1 6 0}$ & $\mathbf{1 6 0 - 1 7 0}$ & $\mathbf{1 7 0 - 1 8 0}$ & $\mathbf{1 8 0 - 1 9 0}$ & $\mathbf{1 9 0 - 2 0 0}$ \\
${ }^{14}$ C-year (a) & $6052 \pm 30$ & $6284 \pm 26$ & $7216 \pm 34$ & $6159 \pm 27$ & $7899 \pm 37$ & $7659 \pm 29$ & $8154 \pm 30$ & $9923 \pm 35$ & $10693 \pm 34$ & $12816 \pm 40$ \\
\hline
\end{tabular}

Table 3. Regression equations for different particle-size classification

\begin{tabular}{|c|c|c|c|c|c|c|}
\hline \multicolumn{7}{|c|}{ Regression equations } \\
\hline Equations & Classification & $a$ & $\boldsymbol{b}$ & $c$ & $d$ & $\mathbf{r}^{2}$ \\
\hline$Y=a+b X$ & $\begin{array}{l}\text { Clay* } \\
\text { Silt } \\
\text { Sand* }\end{array}$ & $\begin{array}{l}17.39 \\
42.05 \\
40.57\end{array}$ & $\begin{array}{r}-2.00 \times 10^{-4} \\
-4.00 \times 10^{-4} \\
6.00 \times 10^{-4}\end{array}$ & & & $\begin{array}{l}0.26 \\
0.16 \\
0.20\end{array}$ \\
\hline$Y=a+b \ln X$ & $\begin{array}{l}\text { Clay } \\
\text { Silt } \\
\text { Sand }\end{array}$ & $\begin{array}{l}21.20 \\
42.86 \\
35.95\end{array}$ & $\begin{array}{r}-0.62 \\
-0.35 \\
0.97\end{array}$ & & & $\begin{array}{l}0.07 \\
0.01 \\
0.02\end{array}$ \\
\hline$Y=a+b X+c X^{2}+d X^{3}$ & $\begin{array}{l}\text { Clay** } \\
\text { Silt** } \\
\text { Sand** }\end{array}$ & $\begin{array}{l}12.88 \\
31.38 \\
55.74\end{array}$ & $\begin{array}{l}24.00 \times 10^{-4} \\
53.00 \times 10^{-4} \\
77.00 \times 10^{-4}\end{array}$ & $\begin{array}{r}-4.00 \times 10^{-7} \\
-8.00 \times 10^{-7} \\
1.00 \times 10^{-6}\end{array}$ & $\begin{array}{r}2.00 \times 10^{-11} \\
3.00 \times 10^{-11} \\
-5.00 \times 10^{-11}\end{array}$ & $\begin{array}{l}0.59 \\
0.79 \\
0.75\end{array}$ \\
\hline
\end{tabular}

$*: \alpha<0.05 ; * *: \alpha<0.01$. 
The corresponding linear functions were statistically significant, except for silt. However, all were rejected due to relatively low coefficients of determination. Third-order polynomial models were statistically very significant for three particle classifications, with higher coefficients of determination.

Our results contrast with Bockheim (1980) and Merritts et al. (1991) who found that logarithmic functions could adequately describe the relationship between clay and soil age, and with Barrett (2001), who reported that changing silt content with time fitted best to linear models. The difference may be attributed to the appearance of a humus horizon (Ah) which had greater clay and silt contents, and less sand than Ap and AB horizons (Figure 2). The clay in the Ah horizon of the Heilu soil was derived from in situ weathering of sand-sized particles or from organic matter, but not from illuviation from the upper Ap horizon. The dry climate in this area conditioned a lower weathering degree and clay formation in the Ah horizon (Figure 2).

\section{Organic carbon, calcium carbonate and $\mathrm{pH}$}

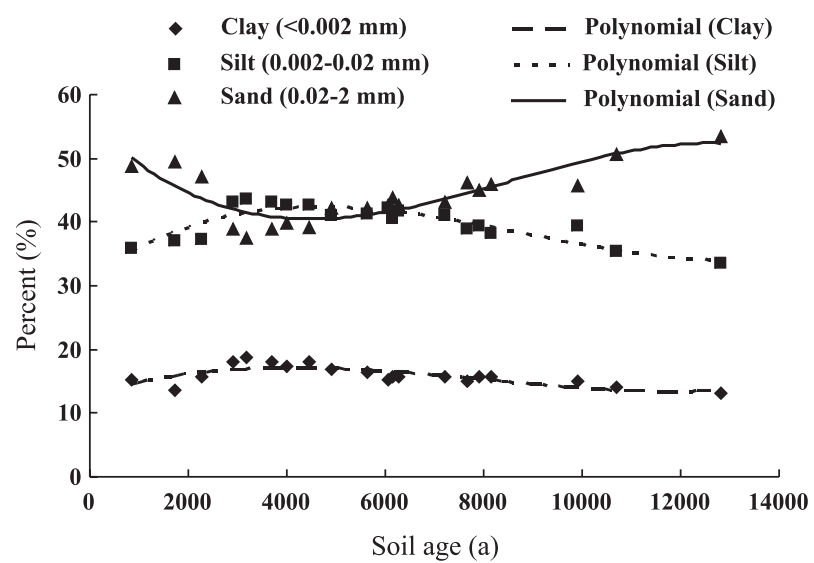

Figure 2. Different particle-size classification as a function of soil age and regression curves of three-order polynomial functions.
Linear, logarithmic and third-order polynomial functions for organic carbon were statistically very significant and the coefficients of determination very high (around 0.8) (Table 4). However, the intercepts of linear and third-order polynomial functions, 0.57 and 0.6 , were lower than 0.66 in the surface layer. Theoretically, the organic carbon content in surface soil should be higher than in any underlying soil layer (Chen, 2005). Data of Tang \& He (2004) in studies on Heilu soil agreed with our results from Luochuan. Therefore, the intercept of logarithmic function, 1.68, was suitable, and was the best fitting chronofunction for organic carbon content (Figure 3).

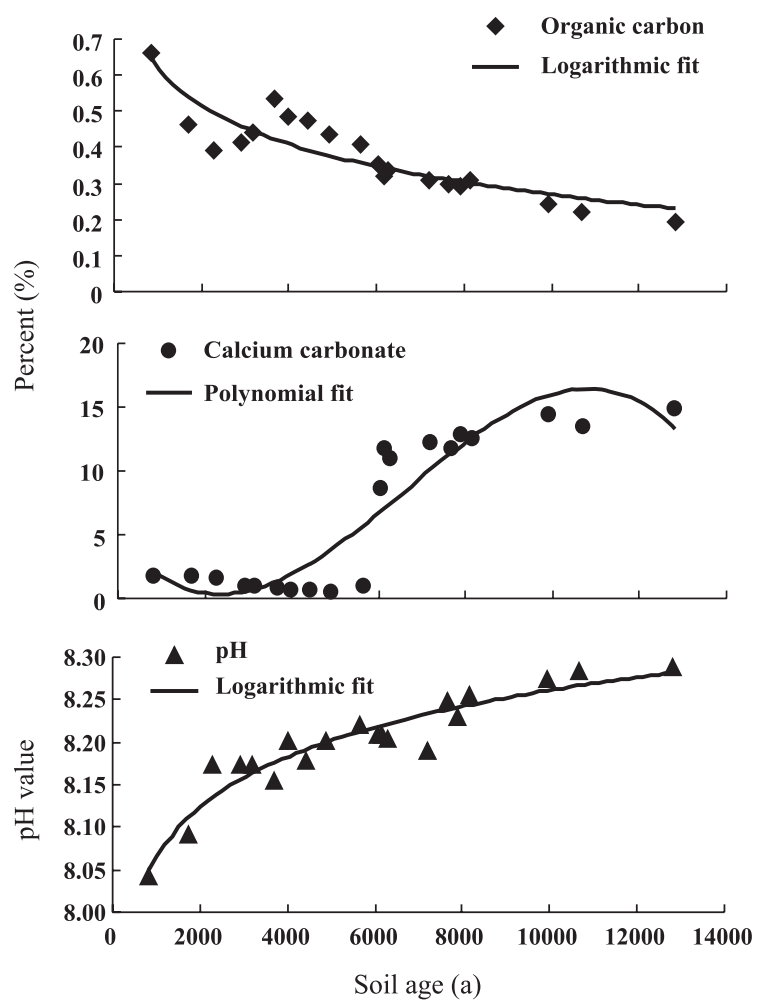

Figure 3. The content of soil organic carbon, calcium carbonate, and $\mathrm{pH}$ as a function of soil age and regression curves

Table 4. Regression equations for organic carbon, calcium carbonate and $\mathrm{pH}$

\begin{tabular}{|c|c|c|c|c|c|c|}
\hline Equations & Property & $a$ & $\boldsymbol{b}$ & $c$ & $d$ & $\mathbf{r}^{2}$ \\
\hline$Y=a+b X$ & $\begin{array}{l}\text { Organic carbon** } \\
\text { Calcium carbonate** } \\
\mathrm{pH}^{* *}\end{array}$ & $\begin{array}{r}0.57 \\
-2.87 \\
8.10\end{array}$ & $\begin{aligned}-3.00 & \times 10^{-5} \\
16.00 & \times 10^{-4} \\
2.00 & \times 10^{-5}\end{aligned}$ & & & $\begin{array}{l}0.79 \\
0.74 \\
0.80\end{array}$ \\
\hline$Y=a+b \ln X$ & $\begin{array}{l}\text { Organic carbon } * * \\
\text { Calcium carbonate } \\
\mathrm{pH}^{* *}\end{array}$ & $\begin{array}{r}1.68 \\
-51.39 \\
7.48\end{array}$ & $\begin{array}{r}-0.15 \\
6.83 \\
0.09\end{array}$ & & & $\begin{array}{l}0.79 \\
0.59 \\
0.90\end{array}$ \\
\hline$Y=a+b X+c X^{2}+d X^{3}$ & $\begin{array}{l}\text { Organic carbon** } \\
\text { Calcium carbonate** } \\
\mathrm{pH}^{* *}\end{array}$ & $\begin{array}{l}0.60 \\
4.78 \\
8.02\end{array}$ & $\begin{aligned}-5.00 & \times 10^{-5} \\
-41.00 & \times 10^{-4} \\
6.00 & \times 10^{-5}\end{aligned}$ & $\begin{array}{l}8.00 \times 10^{-10} \\
1.00 \times 10^{-6} \\
-7.00 \times 10^{-9}\end{array}$ & $\begin{array}{r}2.00 \times 10^{-14} \\
-5.00 \times 10^{-11} \\
3.00 \times 10^{-13}\end{array}$ & $\begin{array}{l}0.81 \\
0.85 \\
0.88\end{array}$ \\
\hline
\end{tabular}

$* *: \alpha<0.01$ 
Although both linear and logarithmic functions for calcium carbonate were statistically very significant and have relatively high $\mathrm{r}^{2}(0.74$ and 0.59$)$, their intercepts were negative (-2.97 and -0.15) (Table 4). Hence, they cannot describe the relationship between calcium carbonate content and soil age. However, this relationship could be best fitted by a third-order polynomial function which has a high $\mathrm{r}^{2}$ value (0.85) and significant statistical results. This chronofunction showed redistribution of calcium carbonate, dissolution in the upper horizon, followed by reprecipitation and enrichment in the lower horizon, and the lowest value was observed in the $\mathrm{Ah}$ horizon (Figure 3). This trend agrees well with the results of Tang \& He (2004) and Zhao et al. (2006) for Heilu soil.

All three functions for $\mathrm{pH}$ were very statistically significant and had high $\mathrm{r}^{2}$ values (Table 4), indicating that theory should be applied this way and adequately incorporated when selecting equations. Huang \& Gong (2001) and Jia et al. (2004) observed that pH values increased with soil age rapidly due to alkalinization, caused by leaching at an initial stage of soil formation, and the increase in deeper horizons was slower. The logarithmic function for $\mathrm{pH}$ represented this trend best (Figure 3).

\section{Mobility of elements in soil}

In many studies, of the relations between selected mobile elements and $\mathrm{Ti}$ or $\mathrm{Zr}$ were used to identify enrichment and depletion of elements with time (Egli \& Fitze, 2000). Since Ti can also be mobilized, $\mathrm{Zr}$ is considered more suitable for this purpose (LangleyTurnbaugh \& Bockheim, 1998; Sauer et al., 2007).

Logarithmic and third-order polynomial functions for $\mathrm{Mn} / \mathrm{Zr}$, Fe/Zr and $\mathrm{K} / \mathrm{Zr}$ were statistically very significant (Table 5). They showed similar trends, in which the ratio increased sharply before about 3000 a B.P., being constant in the older soils (Figure 4). It indicated that mobility or removal of $\mathrm{Mn}, \mathrm{Fe}$ and $\mathrm{K}$ with time was greater in the upper centimeters, whereas depletion or enrichment were negligible in the older lower layers. The third-order polynomial functions were better fitted than logarithmic functions in this study, due to higher $\mathrm{r}^{2}$ (Table 5). On the other hand, the relationships between $\mathrm{Mn}, \mathrm{Fe}, \mathrm{K}$ and time were best fitted by linear and logarithmic functions in studies elsewhere (Koutaniemi et al., 1988; Lichter, 1998; Egli \& Fitze, 2000; Sauer et al., 2007), probably due to different pedological contexts. These results agree well with Tang \& He (2004).

Linear and third-order polynomial functions for $\mathrm{Mg} / \mathrm{Zr}$ were statistically very significant, and had high $\mathrm{r}^{2}$ (0.92 and 0.96) (Table 5). However, they showed different trends (Figure 4). The linear function indicated a constant increase, implying a constant depletion during the Holocene, which seems unlikely, given that the Heilu soil was formed under varying climatic condition (Tang \& He, 2004). In contrast, the third-order polynomial function showed a rapid removal from the surface soil, followed by a slower depletion in older soils, remaining constant in the parent material. But linear and logarithmic increases for different soil chronosequences have been described

Table 5. Regression equations for the ratio of different soil elements and zirconium

\begin{tabular}{|c|c|c|c|c|c|c|}
\hline Equations & Ratio & $a$ & $\boldsymbol{b}$ & $c$ & $d$ & $\mathbf{r}^{2}$ \\
\hline \multirow[t]{7}{*}{$Y=a+b X$} & $\mathrm{Mn} / \mathrm{Zr}^{*}$ & 217.22 & \multicolumn{2}{|c|}{$3.00 \times 10^{-3}$} & & 0.22 \\
\hline & $\mathrm{Fe} / \mathrm{Zr}^{* *}$ & 10362.00 & \multicolumn{2}{|c|}{0.22} & & 0.44 \\
\hline & $\mathrm{K} / \mathrm{Zr}^{* *}$ & 6175.20 & \multicolumn{2}{|l|}{0.15} & & 0.68 \\
\hline & $\mathrm{Na} / \mathrm{Zr} * *$ & 4092.90 & \multicolumn{2}{|l|}{0.10} & & 0.62 \\
\hline & $\mathrm{Ca} / \mathrm{Zr}^{* *}$ & -4439.10 & \multicolumn{2}{|l|}{2.18} & & 0.77 \\
\hline & $\mathrm{Mg} / \mathrm{Zr}^{* *}$ & 3527.00 & \multicolumn{2}{|l|}{0.27} & & 0.92 \\
\hline & $\mathrm{P} / \mathrm{Zr}^{* *}$ & 141.63 & \multicolumn{2}{|l|}{0.01} & & 0.68 \\
\hline \multirow[t]{7}{*}{$Y=a+b \ln X$} & $\mathrm{Mn} / \mathrm{Zr}^{* *}$ & 61.71 & \multicolumn{2}{|l|}{20.39} & & 0.46 \\
\hline & $\mathrm{Fe} / \mathrm{Zr}^{* *}$ & 809.08 & \multicolumn{2}{|l|}{1276.10} & & 0.67 \\
\hline & $\mathrm{K} / \mathrm{Zr}^{* *}$ & 660.09 & \multicolumn{2}{|l|}{751.88} & & 0.78 \\
\hline & $\mathrm{Na} / \mathrm{Zr} * *$ & 1358.60 & \multicolumn{2}{|l|}{392.23} & & 0.41 \\
\hline & $\mathrm{Ca} / \mathrm{Zr}^{* *}$ & -68638.00 & \multicolumn{2}{|l|}{9049.10} & & 0.61 \\
\hline & $\mathrm{Mg} / \mathrm{Zr}^{* *}$ & -5071.10 & \multicolumn{2}{|l|}{1197.70} & & 0.82 \\
\hline & $\mathrm{P} / \mathrm{Zr} \mathrm{r}^{* *}$ & -181.56 & \multicolumn{2}{|l|}{44.99} & & 0.61 \\
\hline \multirow[t]{7}{*}{$Y=a+b X+c X^{2}+d X^{3}$} & $\mathrm{Mn} / \mathrm{Zr}^{* *}$ & 153.32 & 0.04 & $-5.00 \times 10^{-6}$ & $2.00 \times 10^{-10}$ & 0.69 \\
\hline & $\mathrm{Fe} / \mathrm{Zr}^{* *}$ & 7664.10 & 1.65 & $-2.00 \times 10^{-4}$ & $7.00 \times 10^{-9}$ & 0.78 \\
\hline & $\mathrm{K} / \mathrm{Zr}^{* *}$ & 5455.40 & 0.48 & $-4.00 \times 10^{-5}$ & $9.00 \times 10^{-10}$ & 0.81 \\
\hline & $\mathrm{Na} / \mathrm{Zr} * *$ & 4894.30 & -0.44 & $9.00 \times 10^{-5}$ & $-4.00 \times 10^{-9}$ & 0.79 \\
\hline & $\mathrm{Ca} / \mathrm{Zr}^{* *}$ & 5832.50 & -5.34 & $14.00 \times 10^{-4}$ & $-7.00 \times 10^{-8}$ & 0.88 \\
\hline & $\mathrm{Mg} / \mathrm{Zr}^{* *}$ & 3811.10 & -0.04 & $7.00 \times 10^{-5}$ & $-4.00 \times 10^{-9}$ & 0.96 \\
\hline & $\mathrm{P} / \mathrm{Zr}^{* *}$ & 165.90 & 0.02 & $6.00 \times 10^{-6}$ & $-3.00 \times 10^{-10}$ & 0.84 \\
\hline
\end{tabular}

${ }^{*}: \alpha<0.05 ;{ }^{* *}: \alpha<0.01$. 

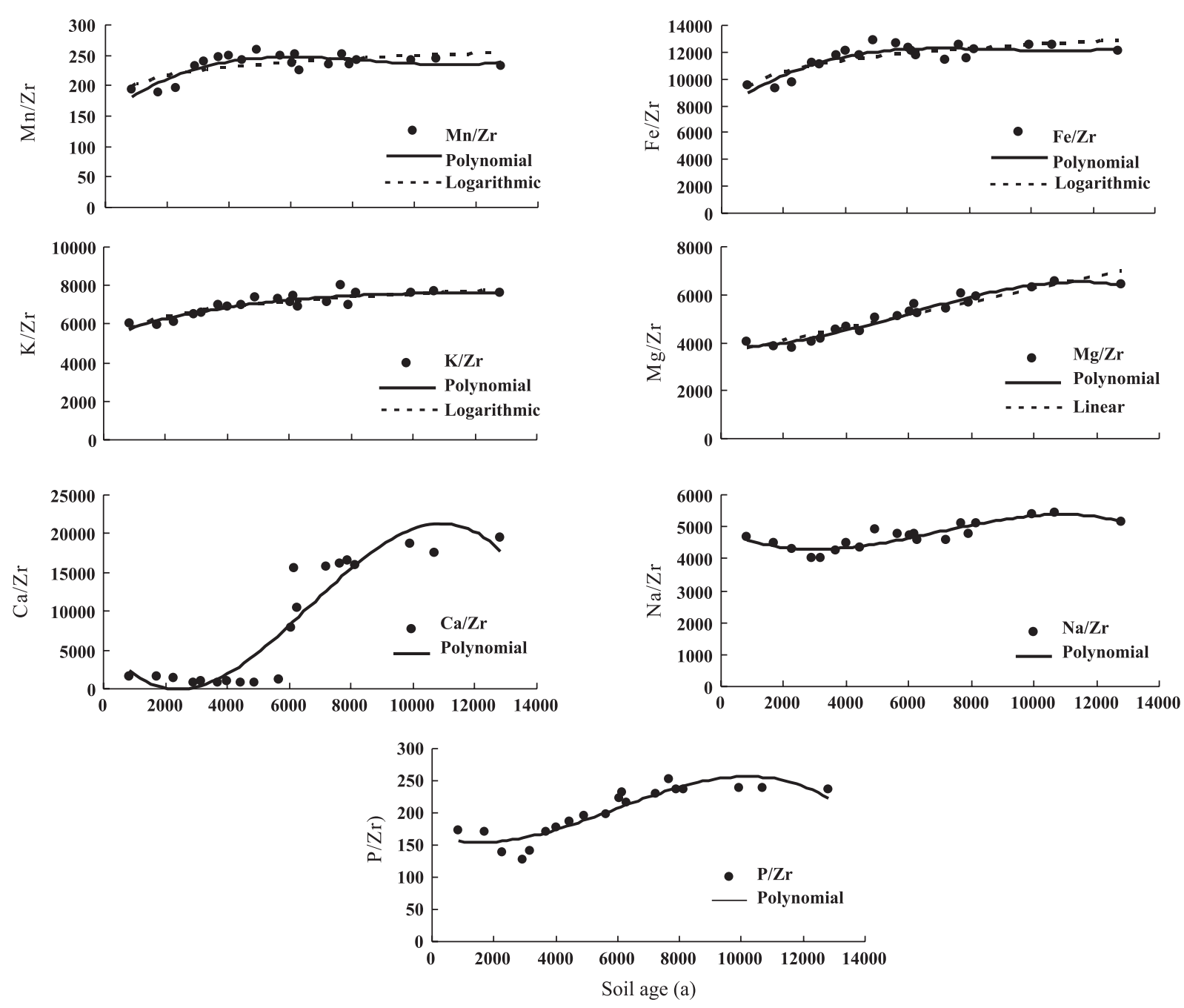

Figure 4. The ratio of $\mathrm{Mn} / \mathrm{Zr}, \mathrm{Fe} / \mathrm{Zr}, \mathrm{K} / \mathrm{Zr}, \mathrm{Mg} / \mathrm{Zr}, \mathrm{Ca} / \mathrm{Zr}, \mathrm{P} / \mathrm{Zr}$, and $\mathrm{Na} / \mathrm{Zr}$ as a function of soil age and regression curves

in many other studies (Koutaniemi et al., 1988; Lichter, 1998; Egli \& Fitze, 2000).

The ratios between the mobile elements $\mathrm{Ca}, \mathrm{P}, \mathrm{Na}$ and "stable" Zr clearly indicated their removal from the upper layers and enrichment downward, with a minimum in the Ah horizon. The steeper slope indicates a faster migration of Ca compared with either $\mathrm{P}$ or Na. However, literature reported that correlations between $\mathrm{Ca}, \mathrm{P}, \mathrm{Na}$ removed with time are described by linear and logarithmic models for non-calcareous soils (Lichter, 1998; Egli \& Fitze, 2000; Sauer et al., 2007).

\section{CONCLUSIONS}

1. In the study of soil chronofunctions, based on soil properties and ${ }^{14} \mathrm{C}$ ages in the Holocene of a typical soil (Heilu) profile developed from loess in Luochuan, linear, logarithmic, and third-order polynomial functions were used to fit the relationships between soil properties and soil ages.

2 . The results indicated that the third-order polynomial function was the best choice to fit the relationships between clay, silt, sand, and soil ages. The trend line confirmed the presence of a humic A horizon in the profile, with higher clay and silt contents attributed to local clay formation and organic matter accumulation.

3. The logarithmic functions explained the variations of soil organic carbon and $\mathrm{pH}$ with time best. The $\mathrm{pH}$ values increased with time and depth, with lower increases in older soils.

4. The variation of $\mathrm{CaCO}_{3}$ content, and ratios between $\mathrm{Mn} / \mathrm{Zr}$, Fe/Zr, $\mathrm{K} / \mathrm{Zr}, \mathrm{Mg} / \mathrm{Zr}$, $\mathrm{Ca} / \mathrm{Zr}, \mathrm{P} / \mathrm{Zr}$, and $\mathrm{Na} / \mathrm{Zr}$ with soil age were best described by three-order polynomial functions. The results indicated that mobility of Mn, Fe and $\mathrm{K}$ with time was greater in the upper layers. The results indicated that the 
mobility and depletion of $\mathrm{Mn}, \mathrm{Fe}$ and $\mathrm{K}$ with time was greater in the upper layers, whereas enrichment of these elements in the lower layers was weak. The chronofunction for $\mathrm{Mg}$ showed a trend to rapid leaching from surface soil, then a slower depletion in older soils, with a constant leaching in parent material. The ratios between $\mathrm{Ca}, \mathrm{P}, \mathrm{Na}$ and $\mathrm{Zr}$ clearly indicated leaching of these elements from the upper centimeters and enrichment in lower soils.

\section{LITERATURE CITED}

BARRETT, L.R. A strand plain soil development sequence in Northern Michigan, USA. Catena, 44:163-186, 2001.

BIRKELAND, P.W. Holocene soil chronofunctions, Southern Alps, New Zealand. Geoderma, 34:115-134, 1984.

BOCKHEIM, J.G. Solution and use of chronofunctions in studying soil development. Geoderma, 24:71-84, 1980.

CHEN, Q.Q.; SHEN, C.D.; SUN, Y.M.; PENG, S.L.; YI, W.X.; LI, Z.A. \& JIANG, M.T. Mechanism of distribution of soil organic matter with depth due to evolution of soil profiles at the Dinghushan Biosphere Reserve. Acta Pedol. Sinica, 42:1-8, 2005.

CHEN, X.Y.; WU, L.G.; LI, S.L. \& LUO, L.P. Genesis and evolution of Heilu soils in the south of Wumeng in the Holocene. Chinese J. Soil Sci., 29:241-244, 1998.

EGLI, M. \& FITZE, P. Formulation of pedologic mass balance based on immobile elements: A revision. Soil Sci., 165:437443, 2000.

FINKE, P.A. \& HUTSON, J.L. Modelling soil genesis in calcareous loess. Geoderma, 145:462-479, 2008.

HEDLEY, M.J.; STEWART, J.W.B. \& CHAUHAN, B.S. Changes in inorganic and organic soil phosphorus fractions induced by cultivation practices and by laboratory incubations. Soil Sci. Soc. Am. J., 46:970-976, 1982.

HU, S.X. Genesis and evolution of heilu soils in the middle and east of Gansu Province. Acta Pedol. Sinica, 31:295304, 1994.

HUANG, C.M. \& GONG, Z.T. Quantitative studies on development of tropical soils: A case study in northern Hainan Island. Earth Sci. J. China University Geosci., 26:314-321, 2001.

HUGGETT, R.J. Soil chronosequences, soil development, and soil evolution: A critical review. Catena, 32:155-172, 1998.

JIA, Y.F.; PANG, J.L. \& HUANG, C.C. pH value's measurement and research of its palaeoclimatic meaning in the Holocene loess section. J. Shaanxi Normal University (Natural Science Edition), 32:102-105, 2004.
KOUTANiEMi, L.; KOPONEN, R. \& RAJANEN, K. Podzolization as studied from terraces of various ages in two river valleys, northern Finland. Silvia Fennica, 22:113-133, 1988.

LANGLEY-TURNBAUGH, S.J. \& BOCKHEIM, J.G. Mass balance of soil evolution on late Quaternary marine terraces in coastal Oregon. Geoderma, 84:265-288, 1998.

LICHTER, J. Rates of weathering and chemical depletion in soils across a chronosequence of Lake Michigan sand dunes. Geoderma, 85:255-282, 1998.

LIU, D.S. Loess deposits in China. Beijing, Science Press, 1965.

MERRITTS, D.J.; CHADWICK, O.A. \& HENDRICKS, D.M. Rates and processes of soil evolution on uplifted marine terraces, northern California. Geoderma, 51:241-275, 1991.

SAUER, D.; SCHELlMANN, G. \& STAHR, K. A soil chronosequence in the semi-arid environment of Patagonia (Argentina). Catena, 71:382-393, 2007.

SCHAETZL, R.J.; BARRETT, L.R. \& WINKLER, J.A. Choosing models for soil chronofunctions and fitting them to data. Europ. J. Soil Sci., 45:219-232, 1994.

SCHLICHTING, E.; BLUME, H.P. \& STAHR, K. Bodenkundliches Praktikum. Berlin, Blackwell Wissenschafts-Verlag, 1995. 295p.

TANG, K.L \& HE, X.B. Revelation on genesis of multi paleosol from Quaternary loess profile. Acta Pedol. Sinica, 39:609617, 2002.

TANG, K.L. \& HE, X.B. Re-discussion on loess-paleosol evolution and climatic change on the Loess Plateau during the Holocene. Quarter. Sci., 24:129-139, 2004.

VINCENT, K.R.; BULL, W.B. \& CHADWICK, O.A. Construction of a soil chronosequence using the thickness of pedogenic carbonate coatings. J. Geol. Educ., 42:316324,1994

VREEKEN, W.J. Principal kinds of chronosequences and their significance in soil history. Europ. J. Soil Sci., 26:378-394, 1975 .

WILCKE, W.; VALLADAREZ, H.; STOYAN, R.; YASIN, S.; VALAREZO, C. \& ZECH, W. Soil properties on a chronosequence of landslides in montane rain forest, Ecuador. Catena, 53:79-95, 2003.

ZHAO, J.B.; HAO, Y.F. \& YUE, Y.L. Change of paleosol and climate during middle Holocene in Luochuan area of Shaanxi Province. Quarter. Sci., 26:969-975, 2006.

ZHOU, W.J.; ZHOU, M.F. \& HEAD, J. ${ }^{14} \mathrm{C}$ chronology of Beizhuang Cun sedimentation sequence since 30,000 years BP. Chinese Sci. B., 35:567-572, 1990.

ZHU, X.M.; LI, Y.S.; PENG, X.L. \& ZHANG, S.G. Soil of the loess region in China. Geoderma, 29:237-255, 1983. 